in practice encouraged attention to the human interests as much as they pave the way for more conscious direction of industrial effort.

The concluding two chapters of this book deservedly merit the attention of scientific workers from their dispassionate attempt to state the outlines of a constructive solution. The days of unbridled competition and selfish individualism are over. The economist and the banker must seek to provide a more stable standard of value which statesmanship must endeavour to secure against external disturbance, and the industrialist must develop improved means of conducting and extending large-scale organisation. The rise of large-scale industrial units is not contrary to the character or tendencies of British economic and political development and is one of the avenues by which a great increase in the material welfare of all classes may be expected. R. Brightman.

\section{Poultry Breeding}

Poultry Breeding. By Morley A. Jull. Pp. xiv + 376. (New York: John Wiley and Sons, Inc.; London: Chapman and Hall, Ltd., 1932.) 23s. net.

$\mathrm{H}$

ERE is a book to be studied by every poultry breeder who wishes to carry the best stock and to secure the maximum benefit from his labour. But it is still more valuable to the naturalist and eugenist, for it is an intensive study of the kaleidoscopic combinations of the genes which govern the characters of poultry-and it is clear to-day that analogous systems of combinations are behind the characters of man and all organisms.

The individual is the product of the factors of heritage and of the factors of the environment, but, whereas the former are fixed, the latter may fluctuate from generation to generation. Poultry in this respect are most suitable 'people' for study, since, being warm-blooded, they are to a large degree independent of climate, and their environment is mainly a matter of feeding and housing, both of which can easily be standardised. Bateson saw this and was at work on his pens of fowl when Mendel's paper on peas was rediscovered, and he continued his researches, Punnett joining him in 1904. This was fortunate, for these workers sought knowledge for its own sake-and the revolution in the industry to-day is the direct outcome of their researches.

The author of the work under notice is the senior poultry husbandman of the United States
Department of Agriculture, and his theme is the experimental study of inheritance in poultry, the setting out and consideration of facts discovered thereby. As he points out, the ideas derived therefrom, and from similar facts relating to other animals, supplant views once held, such as the inheritance of acquired characters, telegony, prepotency and so on. He professedly writes primarily for the breeder, but, as he treats him as an intelligent being, using the modern phraseology, his book is equally valuable to us. Every line of research is reviewed, and a full list of literature added. Chapters on the inheritance of physiological, of linked and of egg-laying characters interest greatly, for they assure us that all features of the essential life processes of an animal are governed by fixed laws.

Yet withal there is plenty of judgment left to the poultry breeder, for he has to select his breeding pens, keeping ever before his mind the necessary combination of egg-laying and table characters. Since neither the author nor Prof. Punnett, who contributes a pleasing foreword, indulge in prophecy arising out of the results put forward, we venture to suggest that a hundred years hence not a single existing breed will be found in our poultry yards; doubtless all the more prominent unit characters that differentiate our breeds will be recognisable, though in strange combinations.

\section{Wireless Communication}

(1) Short Wave Wireless Communication. By A. W. Ladner and C. R. Stoner. Pp. xii $+348+13$ plates. (London: Chapman and Hall, Ltd., 1932.) 15s, net.

(2) La propagation des ondes électromagnétiques: exposé des connaissances acquises, synthèses des idées et des théories. Par Paul Labat. Pp. xii + 445. (Paris : Gauthier-Villars et Cie, 1932.) 80 francs.

(3) Les radio-communications modernes. Par Dr. Pierre David. (Actualités scientifiques et industrielles.) Pp. 150. (Paris : J.-B. Baillière et fils, 1932.) 20 francs.

(1) DURING the past decade the technique of short-wave wireless communication has developed from the erratic experimental stage to its practical and reliable application as a necessary service to modern civilisation. A large proportion of long-distance wireless communication, both telegraphic and telephonic, is now carried out on 